\title{
Valorisation of cold-pressed almond oil's cake as raw material for the preparation of naturally gluten-free flour for specific food applications
}

\author{
Nadia Houmy ${ }^{1,2 *}$, Reda Melhaoui ${ }^{1}$, Souhayla Kodad ${ }^{1}$, Said Zantar ${ }^{3}$ and Ahmed Elamrani ${ }^{1}$ \\ ${ }^{1}$ Laboratory for Agricultural Productions Improvement, Biotechnology and Environment, Faculty of \\ Sciences, University of Mohammed Premier, Oujda, Morocco \\ ${ }^{2}$ Laboratory of Food Technology and Quality, CRRA, INRA, Oujda, Morocco \\ ${ }^{3}$ Laboratory of Food Technology and Quality, CRRA, INRA, Tanger, Morocco
}

\begin{abstract}
Almond cake is a by-product of mechanical press extraction of almond oil intended mainly for the cosmetics industry. According to the circular economy for zero waste, the purpose is to reuse this byproduct to prepare natural gluten-free flour to replace part or all of the whole soft wheat flour (SWF) in specific foods. The almond by-product after grinding was sifted on a sieving shaker equipped with 4 mesh sieves $1 \mathrm{~mm}, 500 \mu \mathrm{m}, 250 \mu \mathrm{m}$, and $100 \mu \mathrm{m}$. The obtained fractions were compared with SWF, based on analysis's results for ash and colour $\left(\mathrm{L}^{*}, \mathrm{a}^{*}, \mathrm{~b}^{*}\right)$, contents of proteins, fibres, total sugars, reducing sugars and bulk density. Significant difference was detected between the gluten free fractions of almond meal and SWF, particularly for protein content and colour. The flour obtained from the almond cake is naturally gluten-free; therefore, it cannot have the properties of a baker's flour of soft Wheat. This naturally gluten free flour would be suitable for gluten free specific baked goods, like cookies, biscuits and crackers, particularly intended to celiac people who cannot consume bakery products made from flour of certain cereals (wheat, barley, rye, oats), or their derivatives.
\end{abstract}

\section{Introduction}

During the past decades, the world demand for vegetable oils for cosmetic and food industries has been increasing continuously thanks to their beneficial effect on the body and health.

Almond (Prunus amygdalus dulcis) fruit possesses high nutritional value and is listed as one of the healthiest nuts. Almonds are used in many savoury dishes and delicacies, but the requirements for extracting almond oil are higher. Almond oil is known for its rich natural antioxidants (tocopherols (vitamin E), polyphenols), which makes it an excellent edible oil, but it is widely used in cosmetics [1-3] due to its profitability. Almond oil extraction generates by-products, almond oil extraction residues known as almond meal or almond cake, which is rich in proteins, fibres and minerals [46], which can be valued.

Morocco is the sixth producer of almonds in the world, with an average production of 102.185 tonnes in 2019 [7]. In the eastern Morocco and thanks to Agriculture Ministry efforts, new cooperatives have started up. Among their profitable activities the extraction of almond oil from defected almond kernels (Almonds broken during mechanical crushing and sorting, shrunken, shriveled, deformed or double kernels), but, generally, at the level of these cooperatives, the byproducts resulting from the extraction of almond oil, remain valueless. Thus, the purpose of this study was to reuse almond oil extraction by-product as raw material to prepare naturally gluten-free flour in order to replace part or all of the soft wheat flour (SWF) for specific food applications.

\section{Material and methods}

\subsection{Plant material and analysis methods}

Cold-pressed almond oil's residues were obtained from the cooperative "Nour" (Madagh, Berkane, Eastern Morocco). The "almond cake" grinding was carried out by a Kinematica / Microtron grinder-mixer to obtain a suitable flour.

$100 \mathrm{~g}$ of ground almond meal was sieved by a sieving shaker (CISA, RP200N) for $15 \mathrm{~min}$ at $2.5 \mathrm{~mm}$ of amplitude. Sieving was done by $1 \mathrm{~mm}, 500 \mu \mathrm{m}, 250 \mu \mathrm{m}$ and $100 \mu \mathrm{m}$ sieves that allow obtaining of four flour fractions: A $(>1000 \mu \mathrm{m}), \mathrm{B}(500-1000 \mu \mathrm{m}), \mathrm{C}(250$ $500 \mu \mathrm{m})$ and $\mathrm{D}(100-250 \mu \mathrm{m})$.

\footnotetext{
Corresponding author: houmy.nadia@gmail.com
} 
The analysed parameters are as follows:

- Bulk density (BD) by ASTM D7481-09 standard [8];

- Colour by Konica Minolta-410 chromamètre according to ISO 11664-4 and L*, $a^{*}, b^{*}$ system [9];

- Total sugars (TS) by Houmy (2020) [4];

- Reduced sugars (RS) by Bertand method;

- Crude fibre (CF) by AOAC (1990) standard [10];

- Ash by AOAC (2003) standard [11];

- Proteins by Kjeldahl method (AFNOR: NF V04407: 2002) and 6.25 as conversion factor [12];

- Gluten was measured by AACC 38-10 Gluten-Hand Washing method [13].

Whole soft wheat flour (SWF) was purchased from the local market for the performance of the comparative analysis.

The sifting and the analysis was performed in triplicate, with the exception of the colour parameter, which was analysed 6 times.

\subsection{Statistical analysis}

Statistical analyses were conducted using Statistical Package for the Social Sciences (SPSS for Windows, version 21, SPSS Inc., Chicago, IL, USA). The normal distribution was verified according to the Shapiro Wilk test. One-way ANOVA statistical analysis and Tukey's post-hoc test was used for means comparison, the significant difference was considered at $P<0.05$ and correlation test was determined by Pearson's coefficient.

\section{Results \& discussion}

From the whole data, the physical and chemical analyses are presented in Tables 1 and 2 and they definitely indicate that the particle size influenced physical and chemical properties.

\subsection{Physical parameters}

\subsubsection{Bulk density}

Bulk density (Table 1) is expressed as the weight of the flour sample in $\mathrm{kg}$ per unit volume of the flour $(\mathrm{kg} / \mathrm{m} 3)$. The measured bulk density(BD) of almond flour (Table 1) varies between the minimum value of 401.20 and the maximum value of $704.13 \mathrm{~kg} / \mathrm{m}^{3}$, for almond flour fractions D and A. The BD of soft wheat flour (498.13 $\mathrm{kg} / \mathrm{m}^{3}$ ) is close to "fraction C" of almond meal (table 1). Significant difference was detected between different particle sizes at $P<0.05$, while no significant difference was detected between "fraction $C$ " of almond meal and SWF, and these results are in agreement with $[14,15]$. We observe that BD decreases with size reduction and this difference is probably associated with chemical composition mainly proteins and mineral contents $[14$, 15]. The carbohydrate content has also been reported to contribute to the high bulk density or heaviness of a flour sample [16, 17]. This density of flours is an important parameter that affects mixing, and baking dough development. In addition, from a nutritional point of view, a low bulk density is advantageous because it results in the consumption of a better quantity of the lighter food, which is beneficial for the consumer's health [18].

\subsubsection{Colour}

According to $\mathrm{L}^{*}$ (Lightness), $\mathrm{a}^{*}$ (redness), $\mathrm{b}^{*}$ (yellowness) from the International Commission on Illumination, the colour parameters of almond flour fractions and SWF were measured and are presented in Table 1. Lightness changed from 45.86 for " $A$ " fraction to 64.52 for " $D$ " compared to SWF that shows 94.95 value. Significant difference with decreasing particle size was detected at $P<0.05$. Lightness decreases when particle size increases. This change is due to an increase in surface area between particle sizes, which allow more reflection of light [14]. Significant difference was detected between lightness of almond flours and SWF. This difference is due to high content of starch in SWF $(75 \%)[19,20]$.

Redness values vary from 7.94 to 11.02 for A and D fractions respectively and are negatively correlated with particle size. The negative redness value observed ( $\mathrm{a}^{*}$ : 0.65) for SWF demonstrates a clear significant difference compared to almond flours. The almond flours' redness is notably due to the almond skin its content of tinctorial compounds and also probably the process conditions of almond oil extraction such as a slight increase in temperature due to pressure and screw speed, which generate non-enzymatic reactions (Maillard and sugar caramelisation) [21].

The values of the yellowness parameter range from 13.55 to 24.46 for A and D almond flour fractions respectively. SWF has the lowest yellowness value (12.37) and a significant difference was detected for these different samples at $P<0.05$.

Table 1. Bulk density $\left(\mathrm{BK}\left(\mathrm{kg} / \mathrm{m}^{3}\right)\right.$; and colour parameters ( $L^{*}$ : lightness; $a^{*}$ : redness; $b^{*}$ : yellowness); for different fractions (A, B, C) of almond cake and wheat flours (SWF).

\begin{tabular}{|c|c|c|c|c|}
\hline Flour sample & BD & $\mathrm{L}^{*}$ & $a^{*}$ & $b^{*}$ \\
\hline A & $\begin{array}{l}704.13 \\
\pm 8.04 \mathrm{~d}\end{array}$ & $\begin{array}{l}45.86 \quad \pm \\
0.72 \mathrm{a}\end{array}$ & $\begin{array}{ll}7.94 & \pm \\
0.20 b & \end{array}$ & $\begin{array}{l}13.55 \pm \\
0.32 \mathrm{~b}\end{array}$ \\
\hline B & $\begin{array}{l}657.45 \\
\pm 7.09 \mathrm{c}\end{array}$ & $\begin{array}{ll}47.99 \quad \pm \\
0.79 b\end{array}$ & $\begin{array}{l}10.20 \pm \\
0.16 \mathrm{c}\end{array}$ & $\begin{array}{l}17.38 \pm \\
0.19 \mathrm{c}\end{array}$ \\
\hline $\mathrm{C}$ & \begin{tabular}{|l|l}
589.83 \\
$\pm 6.83 \mathrm{~b}$ \\
\end{tabular} & $\begin{array}{ll}53.55 \quad \pm \\
0.54 \mathrm{c}\end{array}$ & $\begin{array}{ll}10.90 & \pm \\
0.19 \mathrm{~d} & \\
\end{array}$ & $\begin{array}{l}21.45 \pm \\
0.17 \mathrm{~d}\end{array}$ \\
\hline D & $\begin{array}{l}401.20 \\
\pm 9.93 \mathrm{a}\end{array}$ & $\begin{array}{l}64.52 \quad \pm \\
1.75 \mathrm{~d}\end{array}$ & $\begin{array}{l}11.02 \quad \pm \\
0.17 \mathrm{~d}\end{array}$ & $\begin{array}{l}24.46 \pm \\
0.26 \mathrm{e}\end{array}$ \\
\hline SWF & $\begin{array}{l}498.13 \\
\pm 8.30 \mathrm{~b}\end{array}$ & $\begin{array}{l}94.95 \quad \pm \\
0.13 \mathrm{e}^{2}\end{array}$ & $\begin{array}{ll}-0.65 & \pm \\
0.01 \mathrm{a} & \end{array}$ & $\begin{array}{l}12.37 \pm \\
0.60 \mathrm{a}\end{array}$ \\
\hline
\end{tabular}

The letters a--e present significant difference at $P<0.05$

\subsection{Chemical parameters}

Results for carbohydrate analysis [Total sugars (TS), reduced sugars $(\mathrm{RS})]$, crude fibres $(\mathrm{CF})]$, ash, proteins, and gluten are summarised in Table 2 . 


\subsubsection{Carbohydrate analysis}

The total sugar content (TS) of the almond flour fractions vary between $9.73 \%$ and $17.15 \%$, and there is a significant difference between the almond-cake flour fractions and the wheat flour SWF (TS: 84.84\%). The results are similar to those of Rabadán et al (2017) and Kodad et al (2020) where they reported that the TS values of their almond cake flours ranged between 14.97 $-27.64 \%$ and $16.73-17.42 \%$, respectively $[5,6]$.

Flour fractions from Almond-cake have contents of 0.45 and $0.90 \%$ for reduced sugars (RS), for not dried almonds. Rogel-Castillo (2017) found a rate of RS 0.35 $\%$; while, for the wheat flour SWF this rate of RS is clearly higher $(2.56 \%)$. We have also observed that when the particle size of almond cake flour is reduced, the RS rate will increase, which may be due to the damaged polysaccharides like starch related to the grinding speed in this case of Almond-Cake's flour fractions. However, in this regard, it should be noted that starch (1\%) is not a major carbohydrate component in almonds [19] but it is present at more than $75 \%$ in wheat [20]. Chromatography analysis (data not shown) of almonds for their sugars contents, confirmed that sucrose is the major component in kernels followed by raffinose, glucose, fructose, sorbitol and inositol [19].

Raw almonds are estimated to contain around 12\% crude fibres (CF). For the almond-cake flour fractions, certainly due to the grinding/ sieving operations, the CF content in the flour fractions decreases. It varies from a minimum of $5.75 \%$ (fine fraction $\mathrm{D}$ ) to a maximum of $7.91 \%$ (coarse fraction A). Although the almond-cake flours' CF content decreases with particle size, these values remain always higher than those of whole-wheat flours (CF (SWF):1.3\%). In this regard, a significant difference was observed between analysed samples at $\mathrm{P}<0.05$.

\subsubsection{Ash and protein content}

The data in Table 2 also show that the ash content varies from a minimum of $5.94 \%$ (fine grain $\mathrm{C}$ ) to a maximum of $6.09 \%$ (coarse grain A), and it remains higher than the $1.14 \%$ for whole wheat flour (SWF). Our results on almond-cake obtained from almond oil extraction from mixtures of almond varieties are comparable to the data observed by Adrian et al. (2017) and Houmy et al. (2020) [4, 6], for the Ferragnes and Ferraduel cultivars.

The almond-cake flour fractions (A, B, C, D) have comparable protein contents ranging from 45 to $49 \% \mathrm{DW}$, which are largely higher than whole-wheat flour (SWF) protein content $(8,79 \%$ DW). Proteins are the main components of defatted almond-cake flour, and the registered results in this work are consistent with the literature (Rabadan et al. (2017) [6] Melhaoui et al. (2017) [24]), which reported that the protein content of almond-cakes from Ferragnes and Ferraduel varieties was $45.50 \%$ and $44.85 \%$, respectively.

The gluten rate of whole wheat flour (SWF) was determined, which accounts for $87.65 \%$ of the total protein content; however, no gluten trace was found in the almond-cake flour fractions. Although it is known that almonds are naturally gluten-free, residues from the extraction of almond oil for food and cosmetic purposes have always been regarded as worthless by-products. Currently, they are valued using them as a raw material to prepare natural gluten-free flour for specific foods and baked goods for people with celiac disease.

Albeit the dough produced with gluten-free, flours have wicked rheological properties, which affect the structure and the quality of the final product [25]. Nowadays, gluten-free bakery products are in high demand. They have been frankly improved by assembling different ingredients and blending gluten-free flours from different botanical species (rice, corn, buckwheat) and by adding various soluble proteins, hydrocolloids, and other additives, which are used as texture and structure agents [26].

Table 2. Total sugars (TS), reduced sugars (RS), crude fibre $(\mathrm{CF})$, ash, proteins and gluten content (\% DW) established on the total protein content, for different fractions (A, B, C, D) of almond cake and wheat flours (SWF)

\begin{tabular}{|c|c|c|c|c|c|c|}
\hline $\begin{array}{c}\text { Flour } \\
\text { samples }\end{array}$ & TS & RS & CF & Ash & Proteins & Gluten \\
\hline A & $\begin{array}{c}17.15 \pm \\
0.54 \mathrm{~b}\end{array}$ & $\begin{array}{c}0.45 \pm \\
0.18 \mathrm{a}\end{array}$ & $\begin{array}{c}7.91 \pm \\
0.50 \mathrm{c}\end{array}$ & $\begin{array}{c}6.09 \pm \\
0.02 \mathrm{c}\end{array}$ & $\begin{array}{c}46.24 \pm \\
0.03 \mathrm{c}\end{array}$ & $\mathrm{ND}$ \\
\hline & $14.97 \pm$ & $0.54 \pm$ & $6.14 \pm$ & $6.35 \pm$ & $49.10 \pm$ & $\mathrm{ND}$ \\
$\mathrm{B}$ & $1.38 \mathrm{~b}$ & $0.04 \mathrm{a}$ & $0.67 \mathrm{~b}$ & $0.08 \mathrm{~d}$ & $0.07 \mathrm{~d}$ & \\
\hline C & $13.13 \pm$ & $0.90 \pm$ & $5.63 \pm$ & $5.94 \pm$ & $46.43 \pm$ & $\mathrm{ND}$ \\
& $1.10 \mathrm{~b}$ & $0.01 \mathrm{~b}$ & $0.19 \mathrm{~b}$ & $0.18 \mathrm{~b}$ & $0.23 \mathrm{c}$ & \\
\hline D & $9.73 \pm$ & $0.90 \pm$ & $5.75 \pm$ & $5.98 \pm$ & $45.22 \pm$ & $\mathrm{ND}$ \\
& $0.29 \mathrm{a}$ & $0.04 \mathrm{~b}$ & $0.27 \mathrm{~b}$ & $0.04 \mathrm{bc}$ & $0.06 \mathrm{~b}$ & \\
\hline SWF & $84.84 \pm$ & $2.56 \pm$ & $1.30 \pm$ & $1.14 \pm$ & $8.79 \pm$ & $87.65 \pm$ \\
& $0.88 \mathrm{c}$ & $0.02 \mathrm{c}$ & $0.13 \mathrm{a}$ & $0.01 \mathrm{a}$ & $0.02 \mathrm{a}$ & $7.18 *$ \\
\hline
\end{tabular}

The letters (a,b, c, d) present significant difference at $P<0.05$

\section{Correlation analysis}

In order to study the effect of grinding and particle size of different fractions of almond meal on the studied physical and chemical parameters, Pearson's correlation was tested and presented in Table 3. It was identified as a number between -1 and +1 that indicates the existence of linearity relation of two variables.

The analysis shows that lightness $\left(\mathrm{L}^{*}\right)$ is negatively correlated with TS, while $\mathrm{CF}$ is positively correlated with RS at $P<0.01$. This may be caused by degradation of fibres by grinding process, which can increase the surface area between particle sizes.

On the other hand, $\mathrm{CF}$ is negatively correlated with redness and yellowness colour at $P<0.05$. This is probably due to almond brown skin grinding, which is characterised by brown colour and high content of fibres, [19], and can be found abundantly in almond meal. Negative linearity between RS and TS caused by grinding may release more of reduced sugars. 


\section{Conclusion}

Four fractions of different particle sizes of almond cake were studied and compared with a whole soft wheat flour. The fractions obtained from the almond cake are chemically and physically different from whole soft wheat flour, mainly in lightness and total sugars. This difference, for the most part, is due to the high content of starch in wheat flour. On the other hand, almond meals present a high content of proteins nonetheless naturally gluten-free. Starch and gluten play an essential role in the stability of baked goods and biscuits' texture. Therefore, it is difficult to have the properties of a baker's flour of soft wheat. The incorporation of different ingredients to improve the properties of baker's flour of almond meal allows this naturally gluten free flour to be suitable for gluten free specific baked goods, like cookies, biscuits and crackers, particularly intended to celiac people who cannot consume bakery products made from flour of certain cereals (wheat, barley, rye, oats), or their derivatives.

Table 3. Pearson's Correlation of total sugars (TS), reduced sugars (RS), crude fibre (CF), ash, proteins (Prot), bulk density (BD) and colour for the four almond meal fractions (A, B, C, D)

\begin{tabular}{ccccccccc} 
& TS & RS & CF & Ash & Prot & BD & L* $^{*}$ & $\mathrm{a}^{*}$ \\
\hline RS & -0.67 & & & & & & & \\
& $*$ & & & & & & & \\
CF & 0.67 & -0.70 & & & & & & \\
& $*$ & $*$ & & & & & & \\
Ash & 0.30 & -0.63 & 0.14 & & & & & \\
& & $*$ & & & & & & \\
Prot & 0.43 & -0.51 & -0.07 & 0.81 & & & & \\
& & & & $* *$ & & & & \\
BD & 0.90 & -0.78 & 0.62 & 0.47 & 0.58 & & & \\
& $* *$ & $* *$ & $*$ & & & & & \\
L* & -0.88 & 0.82 & -0.60 & -0.55 & -0.65 & -0.98 & & \\
& $* *$ & $* *$ & $*$ & & $*$ & $* *$ & & \\
$\mathrm{a}^{*}$ & -0.72 & 0.86 & -0.95 & -0.29 & -0.10 & -0.74 & 0.73 & \\
& $* *$ & $* *$ & $* *$ & & & $* *$ & $* *$ & \\
$\mathrm{~b}^{*}$ & -0.85 & 0.92 & -0.81 & -0.51 & -0.45 & -0.92 & 0.93 & 0.92 \\
& $* *$ & $* *$ & $* *$ & & & $* *$ & $* *$ & $* *$
\end{tabular}

$\overline{* * \text { Significant correlation at } 0.01 ; * \text { Significant correlation at }}$ 0.05 .

\section{Acknowledgement}

The authors would like to thank Moroccan Ministry of Education (MENRSFC) for the financial support of this research through the PARA project and the National Institute of Agronomic Research (INRA) for this collaboration

\section{References}

1. S. Arranz, R. Cert, J. Pérez-Jiménez, A. Cert, F. Saura-Calixto. Food. Chem, 110 985-990 (2008)

2. O. Kodad, G. Estopan, T. Juan, and R. Socias i Company. J. of Compos. Anal. 33 161-165 (2014)

3. S. Yada, G. Huang, K. Lapsley. Compos. Anal. 30 80-85 (2013)

4. N. Houmy, R. Melhaoui, K. Belhaj, A. Richel, M. Sindic, C. Hano, S. Kodad, A. Mihamou, M. Addi,
M. Abid and A. Elamrani. E3S Web. Conf 183, 04004 (2020)

5. S. Kodad, R. Melhaoui, N. Houmy, M. Addi, H. Serghini-Caid, A. Elamrani, M. Abid, and A. Mihamou, E3S Web. of Conf. 183, 04005 (2020)

6. A. Rabadán, M. Álvarez-Ortí, R. Gómez, A. PardoGiménez, J. E. Pardoa. Sci. Hortic. Amsterdam., 225 539-546 (2017)

7. FAOSTAT

(2019). http://www.fao.org/faostat/fr/\#data/QC consulted $01 / 25 / 2021$

8. ASTM D7481 - 18: Standard Test Methods for Determining Loose and Tapped Bulk Densities of Powders using a Graduated Cylinder. 2018

9. ISO 11664-4: Colorimétrie — Partie 4: Espace chromatique L*a*b* CIE 1976. (2019)

10. AOAC: Association of Official Analytical Chemists. Standard analysis of crude fibres (1990)

11. AOAC: Association of Official Analytical Chemists. Standard analysis of Ash (2003)

12. AFNOR: NF V04-407: Viandes, produits à base de viandes et produits de la pêche - Détermination de la teneur en azote total et calcul de la teneur en protéines - Méthode Kjeldahl. (2002)

13. J. Ahmed, S. Al-Jassar, L. Thomas. Food hydrocolloid 48 72-83 (2015).

14. AACC 38-10: Gluten - Hand Washing Method. 11 th Edition.

15. J. Ahmed, A. Taher, M. Mulla, A. Al-Hazza, G. Luciano, J. Food. Eng. 186 34-41 (2016)

16. D.I. Gernah, C.C. Ariahu, E.K. Ingbian, A.I. Sengev, Nigerian J. Nutr. Sci. 32. 1. (2011).

17. Oladele A. K. and Aina J. O. Afr. J. Biotechnol. 6 (21), 2473-2476, (2007).

18. O. B. Ocheme, O. E. Adedeji, C. E. Chinma, C. M. Yakubu, U. H. Ajibo. Food Sci Nutr; 6, 1173-1178 (2018)

19. S. Yada, K. Lapsley, and G. Huang. J. Food. Compos. Anal. 24, 469-480 (2011)

20. J. Holm, I. Björck, A. Drews, N.-G. Prof, M. D Asp. Starch 38, 224 à 226 (1986)

21. L. C. Oliveira, M. Schmiele, C. J. Steel. L.W.T. 75, 261-270 (2017)

22. C. Rogel-Castillo, K. Luo, G. Huang, et A. E. Mitchell, J. Agric. Food Chem. 65, 8948-8956 (2017)

23. H. Kunzek, R. Kabbert \& D. Gloyna., Z. Lebensm. Unters. F. A. 208, 233 - 250 (1999)

24. R. Melhaoui, N. Houmy, A. Ben Moumen, M. Sindic, H. Serghini Caid, A. Elamrani « 1ère Edition des Journées Pratiques Francophones des Sciences Analytiques, Marrakech, Maroc, 27-28 Avril (2017)

25. K. Wang, F. Lu, Z. Li, L. Zhao, C. Han, Food Sci. Technol, 37 (2017)

26. M. Witczak L. Juszczak, R. Ziobro, J. Korus Food Hydrocolloid. 28, 353-360 (2012) 